Tropical Journal of Pharmaceutical Research January 2015; 14 (1): $41-46$

ISSN: $1596-5996$ (print); 1596-9827 (electronic)

(C) Pharmacotherapy Group, Faculty of Pharmacy, University of Benin, Benin City, 300001 Nigeria.

All rights reserved.

Available online at http://www.tjpr.org

Original Research Article http://dx.doi.org/10.4314/tjpr.v14i1.7

\title{
Determination of Antioxidant and Anti-Melanogenesis Activities of Indonesian Lai, Durio kutejensis [Bombacaceae (Hassk) Becc] Fruit Extract
}

\author{
Enos Tangke Arung ${ }^{1 *}$, Wiwin Suwinarti ${ }^{1}$, Medi Hendra ${ }^{2}$, Supomo ${ }^{3}$, Irawan \\ Wijaya Kusuma ${ }^{1}$, Dwi Caesarina Nanda Puteri ${ }^{1}$, Huseyin Avni Eroglu ${ }^{4}$, Yong- \\ ung $\mathrm{Kim}^{5}$, Kuniyoshi Shimizu ${ }^{6}$ and Hiroya Ishikawa ${ }^{7 *}$ \\ ${ }^{1}$ Faculty of Forestry, ${ }^{2}$ Faculty of Mathematics and Science, Mulawarman University, ${ }^{3}$ Samarinda Academy of Pharmacy, \\ Samarinda, 75123, Indonesia, ${ }^{4}$ Faculty of Veterinary Medicine, Department of Physiology, University of Kafkas, Turkey, \\ ${ }^{5}$ Department of Herbal Pharmaceutical Engineering, College of Herbal Bio-industry,Daegu Haany University, Gyeongsangbuk- \\ do, South Korea, ${ }^{6}$ Faculty of Agriculture, Kyushu University, ${ }^{7}$ International College of Arts and Sciences, Fukuoka Women's \\ University, Fukuoka, 813-8529, Japan
}

*For correspondence: Email: tangkearung@yahoo.com, ishikawa@fwu.ac.jp; Tel/Fax: +62-541-737081, +81-92-661$2411 / 2415$

Received: 14 May 2014

Revised accepted: 27 November 2014

\begin{abstract}
Purpose: To investigate the antioxidant and anti-melanogenesis activities of Durio kutejensis [Bombacaceae (Hassk.) Becc] fruit extract.

Methods: The fruit flesh of $D$. kutejensis was extracted successively with $n$-hexane, ethyl acetate/EtOAc, and ethanol/EtOH at room temperature repeatedly. The extracts were concentrated in vacuo to yield their residues. Antioxidant properties were analyzed by 2,2'-azino-bis(3ethylbenzothiazoline-6-sulphonic acid) (ABTS, superoxide dismutase (SOD)-like activity, 2, 2-diphenyl-1picrylhydrazyl (DPPH), and oxygen radical absorbance capacity (ORAC) while anti-melanogensis activity was evaluated by tyrosinase enzyme activity and B16 melanoma cell assays (melanin inhibition and cytotoxicity).

Results: The extract $(200 \mu \mathrm{g} / \mathrm{mL})$ showed melanin inhibition by inhibiting melanin formation in B16 melanoma cell by $47 \%$ without cytotoxicity but did not inhibit tyrosinase enzyme activity. The extract (1 - $1000 \mu \mathrm{g} / \mathrm{mL}$ ) also exhibited some level of antioxidant activity including ORAC (0.04 $\pm 0.00 \mu \mathrm{mol} T \mathrm{TE} / \mathrm{mg}$ at $950 \mu \mathrm{g} / \mathrm{mL})$, ABTS $(1.0 \pm 0.2 \%$ at $100.8 \mu \mathrm{g} / \mathrm{mL})$, SOD (IC50, $76.00 \pm 14.6 \mu \mathrm{g} / \mathrm{mL}$, and DPPH $(21.5 \pm$ $0.7 \%$ at $97.39 \mu \mathrm{g} / \mathrm{mL}$ extract concentration).

Conclusion: The fruit extract of Durio kutejensis has antioxidant properties with a potential for treating hyperpigmentation and for use as a skin-lightening agent.
\end{abstract}

Keywords: Durio kutejensis, Antioxidant, Anti-melanogenesis, B16 Melanoma cell Hyperpigmentation, Skin-lightening agent

Tropical Journal of Pharmaceutical Research is indexed by Science Citation Index (SciSearch), Scopus, International Pharmaceutical Abstract, Chemical Abstracts, Embase, Index Copernicus, EBSCO, African Index Medicus, JournalSeek, Journal Citation Reports/Science Edition, Directory of Open Access Journals (DOAJ), African Journal Online, Bioline International, Open-J-Gate and Pharmacy Abstracts

\section{INTRODUCTION}

Melanin is the major pigment responsible for the color of human skin. It is secreted by melanocyte cells in the basal layer of the epidermis [1].
Melanin pigments are formed in specialized pigment-producing cells known as melanocytes, which originate in the neural crest during embryogenesis and are distributed throughout the embryo during its development [2]. 
Melanin biosynthesis (melanogenesis) occurs in a cascade of enzymatic and spontaneous reactions that convert tyrosine to melanin pigments. The initial and rate-limiting step in melanin synthesis is the hydroxylation of tyrosine to dihydroxyphenylalanine or DOPA [3]. DOPAoxidation produces a highly reactive intermediate that is further oxidized to form melanin by a free radical-coupling pathway. If free radicals are inappropriately processed in melanin biosynthesis, hydrogen peroxide $\left(\mathrm{H}_{2} \mathrm{O}_{2}\right)$ is generated, leading to the production of hydroxyl radicals $(\mathrm{HO} \cdot)$ and other reactive oxygen species or ROS [4].

Fruit is a natural product, and Indonesia's remarkable tropical biodiversity includes fruits that have provided significant contributions to national development programs such as those involving food, nutrition, drugs and pharmaceutical agents. In the present study, we evaluated the extract of Durio kutejensis or Lai fruit, an endemic fruit found in East Kalimantan, Indonesia for its antioxidant activities and antimelanogenesis effect (i.e., melanin inhibition in B16 melanoma cells and mushroom tyrosinase inhibition).

\section{EXPERIMENTAL}

\section{Reagents}

Mushroom tyrosinase, trolox, MTT, fluorescein sodium salt and 2,2'-azobis (2methylpropionamidine) dihydrochloride (AAPH) were obtained from Sigma-Aldrich (St. Louis, $\mathrm{MO}$, USA). The 7-methoxycoumarin was from Indofine (Hillsborough Township, NJ). EMEM was from Nissui Chemical Co. (Osaka, Japan). EDTA was from Dojindo (Kumamoto, Japan). $\mathrm{NaOH}, \mathrm{DMSO}$, L-tyrosine, miconazole, L-DOPA, 1.1-diphenyl-2-picrylhydrazyl (DPPH), 2,2'azinobis(3-ethylbenzothiazolin-6-sulfonic acid) (ABTS) and potassium peroxodisulfate were purchased from Wako Pure Chemical Industries (Osaka, Japan). Tris (hydroxymethyl) aminomethane was from Sigma-Aldrich Japan (Tokyo). Other chemicals used were of the highest commercial grade available.

\section{Plant material and extraction}

The fruit (Figure 1) was collected in January 2012 in Samarinda, East Kalimantan, Indonesia. The samples were identified by Dr. Medi Hendra, then authenticated in Bogor Herbarium Institute, Bogor, Indonesia with no. BO 1381469. The voucher specimen (F-12) and deposited in
Laboratory of Physiology, Faculty of Mathemathics and Science, Mulawarman University. The fruit flesh of $D$. kutejensis (90.18 g) was extracted successively with n-hexane (400 mL), ethyl acetate/EtOAc $(250 \mathrm{~mL})$, and ethanol/EtOH $(350 \mathrm{~mL})$ at room temperature repeatedly. The extracts were concentrated in vacuo, and they gave residues of $0.412,0.808$, and $0.254 \mathrm{~g}$, respectively.

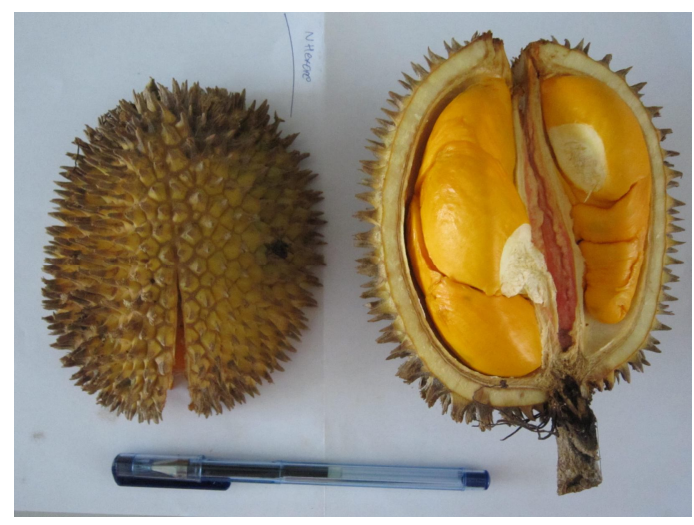

Figure 1: Fruit of $D$. kutejensis (Yellow color is flesh of fruit)

\section{SOD-like (equivalent) activity assay}

SOD-like activity was measured using the SOD assay kit-WST (Dojindo Molecular Technologies, Kumamoto, Japan) according to the manufacturer's instructions. The method involved is based on previous experiments by Ukeda et al [5]. Trolox was used as a positive control.

\section{2,2'-Azino-bis(3-ethylbenzothiazoline-6- sulphonic acid (ABTS) assay}

ABTS assay was mostly based on the method described by $\mathrm{Re}$ et al [6] in which ABTS•+, the oxidant, was generated by persulfate oxidation of ABTS. Specifically, to $5 \mathrm{~mL}$ of $7 \mathrm{mM} \mathrm{ABTS}$ ammonium aqueous solution, $88 \mu \mathrm{L}$ of $140 \mathrm{mM}$ potassium peroxydisulfate $\left(\mathrm{K}_{2} \mathrm{~S}_{2} \mathrm{O}_{8}\right)$ was added, and the resulting mixture was then allowed to stand at room temperature for $12-16 \mathrm{~h}$, yielding a dark blue solution. The mixture was then adjusted by $99.5 \%$ ethanol so that it gave an absorbance of $0.7 \pm 0.02$ units at $734 \mathrm{~nm}$ (UVmini-1240, Shimadzu, Kyoto, Japan) to make the working solution. One milliliter of working solution was mixed with $10 \mu \mathrm{L}$ of extract dissolved in ethanol and shaken well for $10 \mathrm{~s}$; after $4 \mathrm{~min}$ of incubation at $30{ }^{\circ} \mathrm{C}$, the absorbance of the reaction mixture was measured at $734 \mathrm{~nm}$. Trolox was used as positive control. 


\section{DPPH (2,2-diphenyl-1-picrylhydrazyl) assay}

The DPPH assay was performed as described by Arung et al [7]. In brief, the sample was first dissolved in DMSO and used for the actual experiment at 30 times dilution. The reaction mixture contained $967 \mu \mathrm{L}$ of $60 \mathrm{mM}$ DPPH in ethanol and $33 \mu \mathrm{L}$ of sample solution in DMSO. After the reaction was carried out at room temperature for $30 \mathrm{~min}$, the free radical scavenging activity of the sample was quantified by the decolorization of DPPH at $514 \mathrm{~nm}$.

\section{Oxygen radical absorbance capacity (ORAC) assay}

ORAC assay was performed as described by $\mathrm{Ou}$ et al [8] with some modification modification. Briefly, $300 \mu \mathrm{L}$ of the standard (Trolox) or sample solution is mixed with $1.8 \mathrm{~mL}$ of $48 \mathrm{nM} \mathrm{FL}$ solution, and then they were incubated independently at $37^{\circ} \mathrm{C}$ for $15 \mathrm{~min}$. AAPH solution (900 $\mu \mathrm{L} ; 12.9 \mathrm{mM}$, final concentration) was added to the mixture and vortexed for $10 \mathrm{~s}$. Then, it immediately placed in a fluorescence spectrophotometer (Model FP-6500, JASCO Co, Ltd, Tokyo, Japan), and measured every $5 \mathrm{~s}$ for $60 \mathrm{~min}$ at $37{ }^{\circ} \mathrm{C}$ (Ex: $485 \mathrm{~nm}$, Em: $\left.520 \mathrm{~nm}\right)$. A blank (FL + AAPH) using phosphate buffer, standard solutions (6.25-50 $\mu \mathrm{M}$ Trolox), and sample solutions were measured at same conditions. Three independent assays were performed for each sample. The area under the fluorescence decay curve (AUC) was calculated using Eq 1.

$\mathrm{AUC}=1+\{\Sigma(\mathrm{fi} / \mathrm{fo})\}$

where fo is the initial fluorescence reading at 0 $\min$ and $\mathrm{fi}$ is the fluorescence reading at time, $\mathrm{i}$.

The ORAC values were calculated as Prior et al [9] by using a equation $(Y) a+b(X)$ between Trolox concentration $(Y)(\mu M)$ and the net area under the FL decay curve $(X)$. Linear regression was used in the range of $6.25-50 \mu \mathrm{M}$ Trolox. Data are expressed as micromoles of Trolox equivalents (TE) per micromole of sample $(\mu \mathrm{mol}$ $\mathrm{TE} / \mu \mathrm{mol})$.

\section{Tyrosinase assay}

Although mushroom tyrosinase differs somewhat from other sources, this fungal source was used for the present experiment due to its ready availability. It should be noted that commercial tyrosinase was reported to contain numerous proteins in addition to tyrosinase [10] but it was used without purification. In the present study, we determined the tyrosinase activity as described [7]. Kojic acid was used as positive control.

\section{Cell culture}

A mouse melanoma cell line, B16, was obtained from the RIKEN Cell Bank (Ibaraki, Japan). The cells were maintained in Eagle's minimal essential medium (EMEM) supplemented with 10 $\%(\mathrm{v} / \mathrm{v})$ fetal bovine serum (FBS) and 0.09 $\mathrm{mg} / \mathrm{mL}$ theophylline. The cells were incubated at $37^{\circ} \mathrm{C}$ in a humidified atmosphere of $5 \% \mathrm{CO}_{2}$. This assay was determined as described by Arung et al [7] as seen below.

\section{Determination of melanin content in B16 melanoma cells}

The melanin content of the cells after treatment was determined as follows. After we removed the medium and washed the cells with PBS, the cell pellet was dissolved in $1.0 \mathrm{~mL}$ of $1 \mathrm{~N} \mathrm{NaOH}$. The crude cell extracts were assayed using a microplate reader (Bio-Tek, Winooski, VT) at 405 $\mathrm{nm}$ to determine the melanin content. We analyzed the results from the cells treated with the test samples as a percentage of the results from the control culture. Arbutin was used as a positive control.

\section{Determination of cell viability}

We determined the cell viability by the microculture tetrazolium technique (MTT). MTT assay provides a quantitative measure of the number of viable cells by determining the amount of formazan crystals produced by metabolic activity in treated versus control cells. The cultures were initiated in 24-well plates at $1 \times 10^{5}$ cells per well. After incubation, we added $50 \mu \mathrm{L}$ of MTT reagent [3-(4, 5-dimethyl-2-thiazolyl)-2, 5-diphenyl-2Htetrazolium bromide in PBS $(5 \mathrm{mg} / \mathrm{mL})$ ] to each well. The plates were incubated in a humidified atmosphere of $5 \%$ of $\mathrm{CO}_{2}$ at $37{ }^{\circ} \mathrm{C}$ for $4 \mathrm{~h}$. After removing the medium, we added $1.0 \mathrm{~mL}$ isopropyl alcohol (containing $0.04 \mathrm{~N} \mathrm{HCl}$ ) to the plate, and the absorbance was measured at 570 $\mathrm{nm}$ relative to $630 \mathrm{~nm}$.

\section{Statistical analysis}

The $\mathrm{IC}_{50}$ (median inhibition concentration) is the concentration of the compound that reduces the biological activity by $50 \%$ and determined by JMP Pro ver. 9.0.2 (SAS Institute Japan Ltd). Value was given as geometric means. Differences were considered to be statistically significant when $p<0.05$ and $<0.01$. 


\section{RESULTS}

\section{Antioxidant effect of the extract}

The ethyl acetate extract of $D$. kutejensis fruit was more potent as an antioxidant than other extracts. It showed some antioxidant activity in ABTS, SOD-like activity, DPPH, and ORAC assays, as follows: $1.0 \pm 0.2 \%$ at $100.8 \mu \mathrm{g} / \mathrm{mL}$, $76.5 \pm 14.6\left(\mathrm{IC}_{50} \mu \mathrm{g} / \mathrm{mL}\right), 21.5 \pm 0.7 \%$ at 97.4 $\mu \mathrm{g} / \mathrm{mL}, \quad 0.04 \pm 0.0 \quad$ TEAC $(\mu \mathrm{mol} \quad \mathrm{TE} / \mathrm{mg})$, respectively (Table 1). Trolox was used as positive control.

\section{Anti-melanogenesis effect of the extract of $D$. kutejensis}

The tyrosinase enzyme activity of the extract is presented in Table 2, with L-DOPA the as substrate. The extracts did not show tyrosinase inhibition activity, compared with Kojic acid as positive control which inhibited tyrosinase activity.

In the evaluation of melanin inhibition in the B16 melanoma cells, the EtOAc extract of $D$. kutejensis fruit showed more poten than others in melanin inhibition of $46.9 \%$ with no cytotoxicity at $200 \mu \mathrm{g} / \mathrm{ml}$ ) as shown in Table 2. Arbutin, used as positive control showed $62.4 \%$ of inhibition with less toxicity.

\section{DISCUSSION}

Several fruits have been found to have potency as a cosmetic material. Examples include citrus fruits, which contain hesperetin, induce melanogenesis [11]; Cucumis sativus has antihyaluronidase activity [12]; Embelica officinalis has an anti-photoaging effect [13], and Platycarya strobilacea has an anti-wrinkle effect [14]. In Indonesia, the fruit of Langsat (Lansium domesticum) from Central Kalimantan is produced for a cosmetic product offered by the Martha Tilaar Company. The fruit of Limpasu (Baucarea sp.) is produced traditionally in smallscale industrial outfits in South Kalimantan, Indonesia, as Bedak Dingin.

The skin is a major target of oxidative stress caused by reactive species (RS), including reactive oxygen species and reactive nitrogen species. RS is major and significant contributors to skin hyperpigmentation and skin aging [15]. It has generally been believed that agents that have antioxidant activity show anti-aging, whitening, and anti-inflammatory activities [16]. Here we conducted antioxidant assays (ABTS, SOD-like activity, DPPH and ORAC) to determine the ability of the fruit extract to counteract oxidative stress from UV irradiation. The EtOAc extract showed promise as an antioxidant. To the best of our knowledge, this is

Table 1: Effect of Lai (Durio kutejensis) fruit extracts on antioxidant assays

\begin{tabular}{|c|c|c|c|c|}
\hline Samples & ABTS IC ${ }_{50}(\mu \mathrm{g} / \mathrm{ml})$ & $\begin{array}{l}\text { SOD like activity } \\
\text { IC }_{50}(\mu \mathrm{g} / \mathrm{ml})\end{array}$ & DPPH IC $_{50}(\mu \mathrm{g} / \mathrm{ml})$ & $\begin{array}{c}\text { ORAC TEAC ( } \mu \mathrm{mol} \\
\text { TE/mg) }\end{array}$ \\
\hline n-Hexane & $\begin{array}{c}2.6 \pm 0.5 \% \text { (at } 106.8 \\
\mu \mathrm{g} / \mathrm{ml})\end{array}$ & $\begin{array}{c}18.2 \pm 1.0 \% \text { (at } \\
106.8 \mu \mathrm{g} / \mathrm{ml})\end{array}$ & nt & nt \\
\hline EtOAC & $\begin{array}{r}1.0 \pm 0.2 \%(\text { at } \\
100.8 \mu \mathrm{g} / \mathrm{ml})\end{array}$ & $76.5 \pm 14.6$ & $\begin{array}{c}21.5 \pm 0.7 \%(\text { at } \\
97.4 \mu \mathrm{g} / \mathrm{ml})\end{array}$ & $0.04 \pm 0.00$ \\
\hline $\mathrm{EtOH}$ & $\begin{array}{c}2.4 \pm 0.4 \% \text { (at } 101.2 \\
\mu \mathrm{g} / \mathrm{ml})\end{array}$ & $\begin{array}{c}30.2 \pm 9.8 \%(\text { at } \\
101.2 \mu \mathrm{g} / \mathrm{ml})\end{array}$ & nt & $\mathrm{nt}$ \\
\hline Trolox & $30.6 \pm 0.8$ & $246.9 \pm 14.1$ & & \\
\hline
\end{tabular}

nt: not tested. Each column represents the mean $\pm S D$, with $n=3$. The $I C_{50}$ was determined by JMP Pro ver. 9.0.2

Table 2: Anti-melanogenesis effect of $D$. kutejensis fruit extracts (tyrosinase assay and melanin inhibition in B16 melanoma cells)

\begin{tabular}{lccc}
\hline Test agent & L-DOPA $^{\text {a }}(\%$ inhibition) & $\begin{array}{c}\text { Melanin inhibition } \\
(\boldsymbol{\mu g} / \mathbf{m l})\end{array}$ & Cell viability (\%) \\
\hline n-Hexane & No inhibition & & \\
EtOAC & No inhibition & $19.7(\text { at } 200 \mu \mathrm{g} / \mathrm{ml})^{* *}$ & $89.9^{* *}$ \\
EtOH & $05.00(\text { at } 100 \mu \mathrm{g} / \mathrm{ml})^{*}$ & $46.9(\text { at } 200 \mu \mathrm{g} / \mathrm{ml})^{* *}$ & $101.2^{*}$ \\
Kojic acid & $87.9(\text { at } 10 \mu \mathrm{g} / \mathrm{ml})^{* *}$ & $-5(\text { at } 200 \mu \mathrm{g} / \mathrm{ml})^{*}$ & 99.7 \\
Arbutin & - & - & - \\
\hline
\end{tabular}

Note: $a=$ substrate; $b=$ at $100 \mu \mathrm{g} / \mathrm{ml}$; each column represents the mean $\pm S D, n=3) ; p<0.05\left(^{*}\right), p<0.01\left({ }^{* *}\right)$, compared with control; DOPA = 3,4-dihydroxyphenylalanine 
the first report that this fruit extract has the ability to inhibit melanin in B16 melanoma cells along with some antioxidant activities.

Initially, we examined all extracts to tyrosinase inhibitory activity, but no inhibition. Next, we done with B16 melanoma cells to evaluate its melanin inhibition and the EtOAc extract inhibited the melanin production in B16 melanoma cells. Some active compounds might be involved inhibit melanin production in B16 melanoma cells. Rudiyansyah and Garson were reported that wood bark of Durio kutejensis contained triterpenes (3 $\beta$-O-trans-caffeoyl-2 $\alpha$-hydroxyolean-12-en-28-oic acid, 3 $\beta$-O-trans-caffeoyl-2 $\alpha$ -hydroxytaraxest-12-en-28-oic acid, maslinic acid, and arjunolic acid), quinone (2,6-dimethoxyp-benzoquinone), and coumarin (fraxidin) [17]. The active compounds of triterpene, quinone and coumarin were reported as melanin inhibitor [1820]. The extract might not have directly inhibited tyrosinase enzyme but probably acted via signal transduction of melanogenesis in the cells, leading to inhibition of melanin formation. Lam et al stated that some signal transductors such as cyclic adenosine monophosphate (cAMP), protein kinase $A(P K A)$, tyrosinase-related protein (TRP), p38 mitogen-activated protein kinase (MAPK), phosphatidylinositol 3-kinase (PI3K), extracellular signal-regulated kinase (ERK), and microphthalmia associated transcription factor (MITF) play some role in the mechanism of anti-hyperpigmention [21]. However, this hypothesis needs to be tested in further studies. To the best of our knowledge, this is the first report that this fruit extract of Lai has the ability to inhibit melanin in B16 melanoma cells along with some antioxidant activities.

\section{CONCLUSION}

The EtOAc extract of $D$. kutejensis fruit exhibits melanin inhibition with no cytotoxicity, as well as antioxidant activity. Thus, this extract may have potentials for treatment of hyperpigmentation as well as an application skin-lightening agent. However, further studies are necessary to isolate the active compound, evaluate its mechanism of action, as well as ascertain its safety profile.

\section{ACKNOWLEDGEMENT}

This work supported by Directorate General of Higher Education, Indonesia Ministry of National Education in MP3El Project (grant no. 278/SP2H/PL/DIT.LITABMAS/VII/2013.

\section{REFERENCES}

1. Hearing VJ. Biogenesis of pigment granules: a sensitive way to regulate melanocyte function. J Dermatol Sci 2005; 37: 3-14.

2. Sánchez-Ferrer A, Rodrígez-López JN, García-Carmona F. Tyrosinase: a comprehensive review of its mechanism. Biochim Biophys Acta 1995; 1247: 1-11.

3. Yoon JH, Shim JS, Cho Y, Baek NI, Lee CW, Kim HS, Hwang JK. Depigmentation of melanocytes by isopanduratin $A$ and 4-hydroxypanduratin $A$ isolated from Kaempferia pandurata RoxB. Biol Pharm Bull 2007; 30: 2141-2145.

4. Perluigi M, De Marco F, Foppoli C, Coccia R, Blarzino C, Marcante ML, Cini C. Tyrosinase protects human melanocytes from ROS-generating compounds. Biochem Biophys Res Commun 2003; 305: 250-256.

5. Ukeda $H$, Sarker $H$, Kawata AK, Sawamura D. Flow injection assay of superoxide dismutase based on the reduction of highly water-soluble tetrazolium. Anal Sci 1999; 15: 353-357.

6. Re R, Pellegrini N, Proteggente A, Pannala A, Yang M, Rice-evans C. (1999). Antioxidant activity applying an improved ABTS radical cation decolorization assay. Free Radic Biol Med, 26: 1231-1237.

7. Arung ET, Kuniyoshi Shimizu, Ryuichiro Kondo. (2006). Inhibitory effect of artocarpanone from Artocarpus heterophyllus on melanin biosynthesis. Biol Pharm Bull; 29: 1966-1969.

8. Ou B, Hampsch-Woodill M, Prior RL. Development and validation of an improved oxygen radical absorbance capacity assay using fluorescein as the fluorescent probe. J Agric Food Chem 2001; 49: 4619-4626.

9. Prior RL, Hoang $H, G u L, W u X$, Bacchioca M, Howard L, Hampsch-Woodill $M$, Huang $D$, Ou B, Jacob $R$. Assays for hydrophilic and lipophilic antioxidant capacity (oxygen radical absorbance capacity (ORACFL) of plasma and other biological and food samples. J Agric Food Chem 2003; 51: 3273-3279.

10. Flurkey A., Cooksey J, Reddy A., Spoonmore K., Rescigno A., Inlow J, Flurkey WH. Enzyme, protein, carbohydrate, and phenolic contaminants in commercial tyrosinase preparations: potential problems affecting tyrosinase activity and inhibition studies. J Agric Food Chem 2008; 56; 4760-4768.

11. Huang YC, Liu KC, Chiou YL. Melanogenesis of murine melanoma cells induced by hesperetin, a Citrus hydrolysate-derived flavonoid. Food Chem Toxicol 2012; 50: 653-659.

12. Nema NK, Maity N, Sarkar B, Mukherjee PK. Cucumis sativus fruit-potential antioxidant, anti-hyaluronidase, and anti-elastase agent. Arch Dermatol Res 2011; 303: 247-252.

13. Adil MD, Kaiser $P$, Satti NK, Zargar AM, Vishwakarma $R A$, Tasduq SA. Effect of Emblica officinalis (fruit) against UVB-induced photo-aging in human skin fibroblasts. J Ethnopharmacol 2010; 28: 109-114. 
14. Kim YH, Kim KH, Han CS, Yang HC, Park SH, Jang HI, Kim JW, Choi YS, Lee NH. Anti-wrinkle activity of Platycarya strobilacea extract and its application as a cosmeceutical ingredient. J Cosmet Sci 2010; 61: 211-214.

15. Kim YJ, Kang KS, Yokozawa T. The anti-melanogenic effect of pycnogenol by its anti-oxidative actions. Food Chem Toxicol 2008; 46: 2466-2471.

16. Choi MY, Song HS, Hur HS, Sim SS. Whitening activity of luteolin related to the inhibition of CAMP pathway in alpha-MSH-stimulated B16 melanoma cells. Arch Pharm Res 2008; 31: 1166-1171.

17. Rudiyansyah, Garson MJ. Secondary metabolites from the wood bark of Durio zibethinus and Durio kutejensis. J Nat Prod 2006; 69: 1218-1221.
18. Jung E, Lee JA, Shin S, Roh KB, Kim JH, Park $D$. Madecassoside inhibits melanin synthesis by blocking ultraviolet-induced inflammation. Molecules 2013; 18: 15724-15736.

19. Sato K, Toriyama M. Effect of pyrroloquinoline quinone $(P Q Q)$ on melanogenic protein expression in murine B16 melanoma. J Dermatol Sci 2009; 53: 140-145.

20. Kumar CG, Mongolla P, Pombala S, Kamle A, Joseph J. Physicochemical characterization and antioxidant activity of melanin from a novel strain of Aspergillus bridgeri ICTF-201. Lett Appl Microbiol 2011; 53: 350358.

21. Lam RY, Lin ZX, Sviderskaya EV, Cheng $\mathrm{CH}$. Mechanistic studies of anti-hyperpigmentary compounds: elucidating their inhibitory and regulatory actions. Int J Mol Sci 2014; 15: 14649-14668. 